\title{
Evolutionary history of tall fescue morphotypes inferred from molecular phylogenetics of the Lolium-Festuca species complex
}

\author{
Melanie L Hand ${ }^{1,3}$, Noel OI Cogan ${ }^{1,2}$, Alan V Stewart ${ }^{4}$, John W Forster ${ }^{1,2,3^{*}}$
}

\begin{abstract}
Background: The agriculturally important pasture grass tall fescue (Festuca arundinacea Schreb. syn. Lolium arundinaceum (Schreb.) Darbysh.) is an outbreeding allohexaploid, that may be more accurately described as a species complex consisting of three major (Continental, Mediterranean and rhizomatous) morphotypes. Observation of hybrid infertility in some crossing combinations between morphotypes suggests the possibility of independent origins from different diploid progenitors. This study aims to clarify the evolutionary relationships between each tall fescue morphotype through phylogenetic analysis using two low-copy nuclear genes (encoding plastid acetyl-CoA carboxylase [Accl] and centroradialis [CEN]), the nuclear ribosomal DNA internal transcribed spacer (rDNA ITS) and the chloroplast DNA (cpDNA) genome-located matK gene. Other taxa within the closely related Lolium-Festuca species complex were also included in the study, to increase understanding of evolutionary processes in a taxonomic group characterised by multiple inter-specific hybridisation events.
\end{abstract}

Results: Putative homoeologous sequences from both nuclear genes were obtained from each polyploid species and compared to counterparts from 15 diploid taxa. Phylogenetic reconstruction confirmed $F$. pratensis and $F$. arundinacea var. glaucescens as probable progenitors to Continental tall fescue, and these species are also likely to be ancestral to the rhizomatous morphotype. However, these two morphotypes are sufficiently distinct to be located in separate clades based on the ITS-derived data set. All four of the generated data sets suggest independent evolution of the Mediterranean and Continental morphotypes, with minimal affinity between cognate sequence haplotypes. No obvious candidate progenitor species for Mediterranean tall fescues were identified, and only two putative sub-genome-specific haplotypes were identified for this morphotype.

Conclusions: This study describes the first phylogenetic analysis of the Festuca genus to include representatives of each tall fescue morphotype, and to use low copy nuclear gene-derived sequences to identify putative progenitors of the polyploid species. The demonstration of distinct tall fescue lineages has implications for both taxonomy and molecular breeding strategies, and may facilitate the generation of morphotype and/or sub-genome-specific molecular markers.

\section{Background}

The Festuca genus is the largest within the Loliinae subtribe of the Poaceae family, and contains over 500 species of temperate grasses [1]. Species of Festuca vary in morphology, with studies of leaf anatomy and phylogeny based on sequence of the internal transcribed spacer

\footnotetext{
* Correspondence: john.forster@dpi.vic.gov.au

'Department of Primary Industries, Biosciences Research Division, Victorian AgriBiosciences Centre, 1 Park Drive, La Trobe University Research and Development Park, Bundoora, Victoria 3083, Australia

Full list of author information is available at the end of the article
}

(ITS) region of ribosomal DNA (rDNA) consistently defining two major evolutionary lineages, of broad and fine-leaved species [1-6]. The genus also varies substantially in ploidy levels, from diploid $(2 \mathrm{n}=2 \mathrm{x}=14)$ to dodecaploid $(2 \mathrm{n}=12 \mathrm{x}=84)$, the vast majority of species being allopolyploid $[7,8]$. One of the most agriculturally important Festuca species is tall fescue (Festuca arundinacea Schreb.); a broad-leaved outbreeding allohexaploid grass that is cultivated for pasture production throughout the temperate world. Within the Festuca genus, tall fescue has been recognised as belonging,

\section{Biomed Central}

(c) 2010 Hand et al; licensee BioMed Central Ltd. This is an Open Access article distributed under the terms of the Creative Commons Attribution License (http://creativecommons.org/licenses/by/2.0), which permits unrestricted use, distribution, and reproduction in any medium, provided the original work is properly cited. 
along with other mostly polyploidy species, to the Schedonorus sub-genus [2]. This taxonomic classification has been the subject of some controversy, as Schedonorus species share a close relationship with Lolium, the relatively less populated genus of ryegrasses and allied species, which contains ten recognised diploid taxa [9-11]. The monophyly of Schedonorus and Lolium has led to proposals of reclassification, such that the Schedonorus sub-genus is aligned within Lolium and tall fescue is hence renamed Lolium arundinaceum (Schreb.) Darbysh [12]. The Lolium and Festuca genera undoubtedly represent a closely allied complex of related and partially interfertile species. In this study, however, due to comparisons of tall fescue and other broad-leaved species with taxa which remain classified as part of Festuca, the nomenclature and sub-generic classification of Clayton and Renvoize [2] is retained.

The Schedonorus sub-genus is itself a complex species group with considerable ploidy variation resulting from multiple combinatorial hybridisation events. Within this sub-genus, hexaploid tall fescue is a member of a polyploid series that consists of a tetraploid $(F$. arundinacea var. glaucescens Boiss. $=F$. arundinacea subsp. fenas (Lag.) Arcang.), octoploid (F. arundinacea subsp. atlantigena (St. Yves) Auquier) and a decaploid (F. arundinacea subsp. letourneuxiana St. Yves.). Other evolutionary important Schedonorus species include diploid meadow fescue (F. pratensis Huds.), F. pratensis subsp. apennina (De Not.) Hegi (tetraploid), F. mairei St. Yves (tetraploid) and the hexaploid F. gigantea (L.) Vill. The complex evolutionary relationships between these species have to date been studied through the generation of hybrids [13-17], cytological analysis [18], in situ hybridisation [19-22], molecular genetic marker variation $[3,23,24]$ and comparison of chloroplast and rDNA ITS nucleotide sequence [1,4-6].

Further complications arise due to variation within hexaploid tall fescue itself, which may be more accurately described as a species complex. Three major forms of tall fescue have been recognised (Continental, Mediterranean and rhizomatous) that differ in terms of agronomically significant morphological and physiological attributes. These distinct forms are denoted in this study as morphotypes. The summer-active Continental type that predominates in Northern Europe has contributed the majority of temperate cultivated germplasm, and has been the subject of most published tall fescue studies. The Mediterranean type endemic to Northern Africa, parts of Italy and the Middle East displays incomplete summer dormancy and greater winter growth, but lacks winter hardiness as compared to the Continental type $[25,26]$. The two morphotypes also appear to harbor distinctly different symbiotic fungal endophytes of the Epichloë type [27,28].
The third, rhizomatous, morphotype predominates in parts of northern Portugal and Galicia in Spain $[29,30]$ and is distinguished by the presence of both longer and more prevalent rhizomes than those seen in Continental and Mediterranean germplasm, as well as some other distinct taxonomic traits [30,31]. Rhizomatous tall fescue has hence become the target of turf breeding programs due to its superior spreading ability, firstly in New Zealand [32-35] and later in Europe and the USA [36].

The observed differences between the three types would not necessarily be of taxonomic significance, except that $F_{1}$ hybrids between morphotypes, despite being highly vigorous individuals, may display infertility. This property has been reported for crosses between Continental and Mediterranean morphotypes, which display irregular meiotic pairing resulting from extensive multivalent formation [37-43]. Similarly, hybrids between rhizomatous and Mediterranean plants are highly desynaptic, forming numerous univalents at meiosis [43], and hence sterile $[34,36]$. The sterility effects have in part been explained in terms of genetic control of a diploidlike chromosome pairing mechanism in hexaploid tall fescue [44-46]. This mechanism, which may be of broad occurrence in the Poaceae family, does not operate at the haploid level (and is hence termed haplo-insufficient) $[44,45]$. It is also possible that failure of meiotic pairing is due to structural or genomic differences between chromosomes [47]. Many allopolyploid species have arisen more than once from different progenitor ancestral species [48] and it is probable that hexaploid tall fescue follows this pattern, with separate origin events in different regions $[30,49]$.

Attempts to determine the genomic constitution of tall fescue have to date solely focused on the Continental morphotype. Meadow fescue (F. pratensis) has previously been identified as the contemporary taxon most closely related to one of the diploid progenitor sub-genome $(\mathrm{P})$ donors, based on chromosome structure and pairing $[13,17]$ studies. The two remaining sub-genomes $\left(G_{1}\right.$ and $\left.G_{2}\right)$ have been attributed to the tetraploid $F$. arundinacea var. glaucescens, based on genomic in situ hybridisation (GISH) and other molecular genetic techniques $[19,20,23]$. The genomic constitution of Continental tall fescue has therefore been designated $P P G_{1} G_{1} G_{2} G_{2}$.

Although multiple studies of Festuca genus phylogeny have been performed [1,3-6,24], none as yet have included multiple tall fescue morphotypes. Furthermore, the methods employed were limited in capacity to identify each putative progenitor of an allopolyploid species. Genes present in single copy or low copy-number within the nuclear genome have become increasingly popular for studying plant phylogenies [50] and have been used to determine the hybrid origins of polyploid species [51-54]. As compared to the sequences that have been 
traditionally used for molecular evolutionary studies, nuclear genes provide sequence evolution rates elevated in comparison to chloroplast DNA (cpDNA) and rDNA [55,56], are biparentally inherited (in contrast to cpDNA) and are less frequently subjected to concerted evolution than rDNA [57]. This study aims to compare the sequence of two protein-coding genes (Acc1 [encoding plastid acetyl-CoA carboxylase] and $C E N$ [the floral developmental identity-determining gene centroradialis, also known as terminal flower 1]) obtained from all three tall fescue morphotypes, along with some other species of section Schedonorus, and taxa previously identified as putative diploid progenitors. The Acc1 gene is present as a single copy in Triticum (wheat) species on the homoeologous group 2 chromosomes [58] and has been used to achieve high phylogenetic resolution and identify the hybrid origins of a number of polyploid species [59-61]. The CEN gene has been previously isolated and characterised in perennial ryegrass (Lolium perenne L.) and although Southern hybridisation studies revealed two gene copies in this species, only one was detected and isolated from a genomic library [62]. The $L p C E N$ gene has been previously mapped to perennial ryegrass linkage group 5 [63]. Given the large extent of macrosynteny between the genomes of the Triticeae cereals and both Lolium and Festuca species, the allohexaploid tall fescue $A c c 1$ and CEN orthologues are likely to be located on homoeologous linkage groups 2 and 5, respectively [64-66]. The value of the $C E N$ gene for molecular phylogenetics studies in Poaceae species has been evaluated here for the first time. This study is hence aimed at increasing knowledge of evolutionary relationships between each tall fescue morphotype, and other species of the Schedonorus sub-genus through the use of three classes of gene sequence: the nuclear rDNA ITS region, the two low-copy nuclear genes, and the cpDNA maturase $K$ (matK) gene, which has been adopted as an international standard for DNA 'barcoding' [67] and provides evidence for maternal progenitor identity.

\section{Methods}

\section{Orthology assessment}

Exonic regions of the wheat Acc1 (GenBank accession EU660902) and the perennial ryegrass CEN (GenBank accession AF316419) nuclear genes were used as subject queries in BLASTN analysis [68] of the Brachypodium distachyon genome sequence $8 \mathrm{X}$ release [69], to determine copy number in the model species, and hence probable abundance of predicted orthologues (defined at a threshold level of $\mathrm{E}<10^{-50}$ ) in Festuca species.

\section{Sampling and DNA Extraction}

Sampling of Lolium/Festuca taxa was designed to include the three tall fescue morphotypes along with diploid and polyploid species that are thought to share common subgenomes (Table 1). A sample from the related grass species crested dog's-tail (Cynosurus cristatus L.) was chosen as an out-group for all datasets. Seed of each tall fescue morphotype was supplied by PGG Wrightson Seeds, apart from the Continental cultivar KY31, which was obtained from the Royal Barenbrug Group. The remainder of the samples used were sourced from the Genetic Resources Unit, Institute for Biological, Environmental and Rural Studies (IBERS), Aberystwyth, Wales. Genomic DNA was extracted from freeze-dried leaf tissue from one individual per cultivar or accession, using the DNeasy Plant Mini Kit (Qiagen)

\section{Ploidy Analysis}

Ploidy levels for each sample were confirmed using flow cytometric measurements obtained using a Partec Ploidy Analyser instrument. For each cultivar or accession, the single individual from which genomic DNA was extracted was also used for DNA content measurement. Nuclei were extracted from fresh leaf tissue and stained using CyStain UV precise $\mathrm{P}$ (Partec) according to the manufacturer's instructions. Prepared samples were immediately analysed using ultraviolet (UV) light excitation, and duplicate readings were obtained for each sample. A total of two separately prepared samples were measured for each individual tall fescue plant. The genome size for each species was measured relative to $F$. pratensis (as a confirmed diploid standard) and then compared to previously published relative genome sizes $[8,18,70,71]$.

\section{PCR Amplification}

PCR reactions were established in total volumes of $20 \mu \mathrm{l}$, containing $1 \times$ Immolase PCR buffer, $1.5 \mathrm{mM}$ $\mathrm{MgCl}_{2}, 200 \mu \mathrm{M}$ dNTPs, $0.25 \mu \mathrm{M}$ each primer (listed in Table 2), 0.4 units Immolase DNA polymerase (Bioline) and $10 \mathrm{ng}$ template genomic DNA. For the Acc1 and rDNA ITS regions, PCR programs were as previously described (references listed in Table 2). The CEN gene fragment was amplified using a touchdown PCR program consisting of $95^{\circ} \mathrm{C}$ for 15 minutes, 10 cycles of $95^{\circ} \mathrm{C}$ for 30 seconds, $65^{\circ} \mathrm{C}$ for 30 seconds decreasing $1^{\circ} \mathrm{C}$ per cycle, $72^{\circ} \mathrm{C}$ for 2 minutes, followed by 25 cycles of $95^{\circ} \mathrm{C}$ for 30 seconds, $55^{\circ} \mathrm{C}$ for 30 seconds to $72^{\circ} \mathrm{C}$ for 2 minutes and a final extension of $72^{\circ} \mathrm{C}$ for 7 minutes. To amplify the mat $K$ gene region, the same touchdown protocol was used with an altered initial annealing temperature of $60^{\circ} \mathrm{C}$.

\section{Cloning and Sequencing}

All $A c c 1$ and $C E N$ amplification products were subcloned into the $\mathrm{pCR}^{\circ} 4-\mathrm{TOPO}^{\circ}$ vector using the $\mathrm{TOPO}^{\circ}$ TA Cloning ${ }^{\circ}$ Kit for Sequencing (Invitrogen) and were transformed into TOPO10 chemically competent $E$. coli 
Table 1 List of samples included in the study and details of ploidy levels and origin

\begin{tabular}{|c|c|c|c|c|c|c|}
\hline \multirow[t]{2}{*}{ Taxon } & \multirow[t]{2}{*}{ Ploidy } & \multirow[t]{2}{*}{ Origin } & \multirow[t]{2}{*}{ Sub-genus } & \multirow[t]{2}{*}{$\begin{array}{c}\text { IBERS } \\
\text { Accession } \\
\text { Identifier }\end{array}$} & \multicolumn{2}{|c|}{$\begin{array}{c}\text { Number of } \\
\text { distinct } \\
\text { haplotypes }\end{array}$} \\
\hline & & & & & Acc1 & CEN \\
\hline Festuca arundinacea Schreb. & $6 x$ & & & & & \\
\hline Jesup & & Continental cultivar & Schedonorus & N/A & 3 & 3 \\
\hline Quantum & & Continental cultivar & Schedonorus & N/A & 3 & 3 \\
\hline KY31 & & Continental cultivar & Schedonorus & N/A & 3 & 3 \\
\hline Resolute & & Mediterranean cultivar & Schedonorus & N/A & 2 & 2 \\
\hline PG4012 & & Mediterranean breeding line & Schedonorus & N/A & 2 & 2 \\
\hline Torpedo ॥ & & Rhizomatous cultivar & Schedonorus & N/A & 3 & 3 \\
\hline CT2093R & & Rhizomatous breeding line & Schedonorus & N/A & 3 & 3 \\
\hline Festuca pratensis Huds. & $2 x$ & Tadham Moor (Great Britain) & Schedonorus & BF1199 & 1 & 1 \\
\hline Festuca pratensis subsp. apennina (De Not.) Hegi & $4 x$ & Le Moleson (Switzerland) & Schedonorus & BF954 & 2 & 2 \\
\hline Festuca arundinacea var. glaucescens Boiss & $4 x$ & Aoiz (Spain) & Schedonorus & BN581 & 2 & 2 \\
\hline Festuca mairei St. Yves & $4 x$ & Marrakesh (Morocco) & Schedonorus & BS3065 & 2 & 2 \\
\hline Festuca gigantea (L.) Vill. & $6 x$ & Unspecified & Schedonorus & BS5001 & 2 & 3 \\
\hline Festuca arundinacea subsp. atlantigena (St. Yves) Auquier & $8 x$ & Unspecified & Schedonorus & BN865 & 3 & 2 \\
\hline Festuca arundinacea subsp. letourneuxiana St. Yves & $10 x$ & Agadir Gouj (Morocco) & Schedonorus & BN812 & 4 & 4 \\
\hline Festuca drymeja Mert. \& Koch & $2 x$ & (Hungary) & Drymanthele & BS3675 & 1 & 1 \\
\hline Festuca altissima All. & $2 x$ & Koskeg (Hungary) & Drymanthele & BS4384 & 1 & 1 \\
\hline Festuca lasto & $2 x$ & Los Barrios (Spain) & Drymanthele & BS3748 & 1 & 1 \\
\hline Festuca scariosa (Lag) Asch. \& Graebn. & $2 x$ & Unspecified & Scariosae & BS3278 & 1 & 1 \\
\hline Festuca pallens Host. & $2 x$ & Gyulakeszi (Hungary) & Festuca & BL2811 & 1 & 1 \\
\hline Festuca circummediterranea Patzke & $2 x$ & Colle Sanson (Italy) & Festuca & BL2787 & 1 & 1 \\
\hline Festuca rupicaprina (Hackel) A. Kerner & $2 x$ & Unspecified & Festuca & BL2767 & 1 & 1 \\
\hline Festuca tatrae (Czako) Degen & $2 x$ & Unspecified & Festuca & BL2758 & 1 & 1 \\
\hline Festuca ovina $\mathrm{L}$. & $2 x$ & Ponterwyd (Great Britain) & Festuca & BL2643 & 1 & 1 \\
\hline Festuca valesiaca Schleicher ex Gaudin & $2 x$ & Pregradnaya (Russia) & Festuca & BL2506 & 1 & 1 \\
\hline Lolium perenne L. & $2 x$ & Cultivar 'Aurora' & - & N/A & 1 & 1 \\
\hline Lolium multiflorum Lam. & $2 x$ & Cultivar 'Andrea' & - & N/A & 1 & 1 \\
\hline Lolium temulentum L. & $2 x$ & & - & BA13157 & 1 & 1 \\
\hline Cynosurus cristatus L. & $2 x$ & Ponterwyd (Great Britain) & - & BG527 & 1 & 1 \\
\hline
\end{tabular}

$\mathrm{N} / \mathrm{A}=$ not applicable

cells following manufacturer's instructions. For each plant accession-gene combination, 12 colonies were picked for each predicted diploid sub-genome, and the recombinant plasmid DNA was amplified using the

Table 2 Details of primer pairs used to amplify the rDNA ITS region and the matK, ACc1 and CEN genes

\begin{tabular}{lllc}
\hline $\begin{array}{l}\text { DNA } \\
\text { region }\end{array}$ & $\begin{array}{l}\text { Primer } \\
\text { name }\end{array}$ & Primer sequence $\mathbf{5}^{\prime} \mathbf{-} \mathbf{3}^{\prime}$ & Reference \\
\hline Accl & Acc1f1 & GTTCCTGGCTCCCCAATATTATC & {$[59]$} \\
& Acc1r1 & TTCAAGAGATCAACTGTGTAATCA & {$[59]$} \\
CEN & CENf1 & TAAGCAGCCCAAGCCCTTCAAAG & This paper \\
& CENr3 & CGAGGAAGTAATGTAGAAGAGGAGC & This paper \\
ITS & ITSL & TCGTAACAAGGTTCCGTAGGTG & {$[72]$} \\
& ITS4 & TCCTCCGCTTATTGATATGC & {$[72]$} \\
matK & S5-1F & ACCCTGTTCTGACCATATTG & {$[94]$} \\
& trnK-2R & AACTAGTCGGATGGAGTAG & {$[95]$} \\
\hline
\end{tabular}

TempliPhi DNA Sequencing Template Amplification Kit (GE Healthcare). The amplified template was diluted with the addition of $56 \mu \mathrm{l}$ of $\mathrm{ddH}_{2} \mathrm{O}$ and $2 \mu \mathrm{l}$ used as template for sequencing with $\mathrm{T} 7$ and $\mathrm{T} 3$ primers. Each sequencing reaction contained $5 \mu \mathrm{l}$ total volume and contained $0.16 \mu \mathrm{M}$ primer, $0.125 \mu$ BigDye $^{\odot}$ Terminator v3.1 (Applied Biosystems), $0.875 \times$ BigDye $^{\circ}$ Sequencing Buffer (Applied Biosystems) and was subjected to cycling conditions as described in the BigDye ${ }^{\circ}$ v.3.1 protocol. The extension products were purified with ethanol, sodium acetate and EDTA following the BigDye ${ }^{\circ}$ v3.1 protocol (Applied Biosystems) and electrophoresis was performed on the ABI3730xl automated capillary electrophoresis platform.

The amplified ITS and mat $K$-derived amplicons were purified using Exonuclease I and shrimp alkaline phosphatase and a total of $0.5 \mu \mathrm{l}$ purified PCR product was sequenced in a $10 \mu \mathrm{l}$ total volume reaction containing 
the previously listed reagents, with amendment of the volume of BigDye ${ }^{\oplus}$ v.3.1 $(0.25 \mu \mathrm{l})$. The ITSL, ITS4, ITS2 and ITS3 primers [72] were used to fully sequence the ITS region, and the matK gene was sequenced using the amplification primers.

\section{Sequence alignment and analyses}

To separate homoeologous sequence haplotypes derived from Acc1 and CEN, all sequences obtained from each sample were first aligned using Sequencher 4.7 (Gene Codes). Pairwise distances between all sequences from a given accession were calculated using the maximum composite likelihood nucleotide substitution model implemented in MEGA version 4 [73]. The diploid samples were first analysed to determine a $\mathrm{p}$ value threshold that could be used to discriminate between probable allelic (homologous) variation and homoeologous sequence diversity. Each identified group of sequences falling below this threshold were then separately aligned, and consensuses were defined for phylogenetic analysis. These putative homoeologous consensus sequences are hereafter described as haplotypes.

For each gene, all haplotypes were aligned using Sequencher 4.7 (Gene Codes) and edited manually as required. For the directly sequenced ITS and matK gene products, ambiguous bases were denoted using the standard IUPAC ambiguity codes, and boundaries of the ITS spacers and the $5.8 \mathrm{~S}$ gene were determined as previously described [4]. For Acc1 and CEN, intron-exon boundary coordinates were estimated according to those previously determined in bread wheat (Triticum aestivum L.) [58] and perennial ryegrass [62]. Measures of variation (variable sites, parsimony informative sites and indels) within the aligned contigs were calculated using MEGA version 4 [73] and DnaSP version 4.90.1 [74].

\section{Phylogenetic reconstruction}

Prior to performing phylogenetic analysis, all gaps were coded as binary characters using GapCoder [75]. For each data matrix, parsimony analysis was performed using PAUP* v4.0b10 [76] with heuristic search options, TBR branch swapping and 1000 replicates of random sequence addition. Characters were equally weighted and statistical support was achieved through bootstrapping using 1000 replicates [77].

C. cristatus was used as an out-group species for all data sets, and sequences deposited in GenBank from kentucky bluegrass (Poa pratensis L.) and B. distachyon were used as more distant out-group species for the more conserved rDNA ITS and mat $K$ sequence datasets (GenBank accessions AY237833, AF303399, AF164402, AM234568). The B. distachyon Acc1 and CEN genes identified in the orthology assessment were also used as out-group sequences for each respective nuclear gene data set. The Incongruence Length Difference test [78] was used to assess congruence between the nuclear gene data sets and was implemented in PAUP* v4.0b10 through the partition homogeneity test with 1000 replicates.

\section{Results}

\section{Orthology assessment}

The largest exons (numbers eight and ten of Acc1, and two and four of $C E N$ ) were used to search the Brachypodium distachyon genome sequence. For both genes, BLASTN analysis retrieved a single sequence with a below-threshold E value. The $A c c 1$ orthologue is located on $B$. distachyon chromosome 5 , corresponding to the predicted gene bd5g03860, while the CEN orthologue is annotated as predicted gene bd4g42400 on chromosome 4 .

\section{Ploidy analysis}

For all but one sample tested, the relative genome size did not differ by greater than 0.6 -fold when calculated using either the measurements of the Ploidy Analyser or from genome size values previously published (Additional file 1). These samples were therefore deemed to have the predicted ploidy level (Table 1). The F. rupicaprina sample differed by over two-fold when comparing the two relative genome size measurements, and was subsequently removed from all further analysis.

\section{Isolation of homoeologous sequences}

For both Acc1 and CEN, the analysis of pairwise distance between sequences from diploid samples failed to produce a $\mathrm{p}$ value of greater than 0.01 . Therefore, variation between any two sequences with a $p$ value less than 0.01 was predicted to be the result of allelic variation or sequence error. For the polyploid samples, sequences with a $\mathrm{p}$ value of greater than 0.01 were therefore considered likely to be of different sub-genome origin. Each identified group of homoeologous sequences were separately aligned and consensuses were defined for phylogenetic analysis. The number of haplotypes identified for each sample is detailed in Table 1.

\section{Sequence analysis}

ITS

The amplified ITS region used for phylogenetic analysis consisted of the gene encoding the $5.8 \mathrm{~S}$ ribosomal subunit, as well as the two ITS regions that separate this gene from the $18 \mathrm{~S}$ and $26 \mathrm{~S}$ ribosomal subunit genes (ITS1 and ITS2 respectively). The amplified region ranged from 595 to $599 \mathrm{bp}$, length variation being attributable to the ITS1 spacer. Both the $5.8 \mathrm{~S}$ and ITS2 regions were the same length for all samples, at 269 and $101 \mathrm{bp}$ respectively. After alignment of all ITS sequences, the total contig length was $610 \mathrm{bp}$ and contained 174 variable sites 
and 100 parsimony informative sites (Table 3). A total of 25 of the 33 sequenced samples contained at least one ambiguous base. These sequences were deposited in GenBank under the accession numbers HM453173 HM453199 and the final sequence alignment is included as Additional File 2. For each sample, the generated ITS sequence was compared to accessions from the same species that were previously submitted in GenBank from other studies. This evaluation, along with the comparisons of genome size calculated in this study with prior reports in the literature, was used to confirm the identity of each species.

\section{matk}

The amplicon generated using the published matK primers contained an extra 65 and 288 bp from the 5'- and 3'-boundaries, respectively, of the matK gene. However, only the gene itself was used for analysis. These sequences were deposited in GenBank under the accession numbers HM453050 - HM453076 and the final sequence alignment is included as Additional File 3. The matK gene was 1542 bp in length for all samples with the exception of $C$. cristatus (1545 bp). The total contig length used for phylogenetic analysis was $1545 \mathrm{bp}$ and contained 179 variable sites, and 70 parsimony informative sites (Table 3 ).

Acc1

For the majority of taxa, the number of haplotypes obtained was equivalent to the number of predicted subgenomes for each species (Table 1). The exceptions were $F$. gigantea, $F$. arundinacea subsp. atlantigena, $F$. arundinacea subsp. letourneuxiana and the two Mediterranean morphotype varieties Resolute and PG4012, for which the number of derived haplotypes was one less than the ploidy level. The amplified gene fragment contained

Table 3 Characteristics of each sequenced region

\begin{tabular}{lcccc}
\hline & \multicolumn{4}{c}{ Gene } \\
\cline { 2 - 6 } & Acc1 & CEN & ITS & matK \\
\hline Total aligned length (bp) & 2254 & 972 & 610 & 1545 \\
Exon length (bp) min-max & $40-188$ & $41-218$ & - & - \\
Average exon length & 101 & 128 & - & - \\
Exon std dev min-max & $0-0$ & $0-0$ & - & - \\
Intron length (bp) min-max & $73-493$ & $82-958$ & - & - \\
Average intron length & 110 & 119 & - & - \\
UTR length (bp) min-max & - & $42-56$ & - & - \\
Average UTR length & - & 55 & - & - \\
Exon + intron + (UTR) length (bp) min- & $1525-$ & $903-$ & - & - \\
max & 1946 & 958 & & \\
Average exon + intron + (UTR) length & 1572 & 925 & - & - \\
(bp) & & & & \\
Variable sites & 492 & 275 & 174 & 179 \\
Parsimony informative sites & 199 & 122 & 100 & 70 \\
Indels & 112 & 44 & 22 & 4 \\
Indel length (bp) min-max & $1-413$ & $1-32$ & $1-4$ & $6-9$ \\
\hline
\end{tabular}

8 exons and 7 introns, corresponding to exons 6 to 13 of the full-length wheat gene. The total length ranged from 1525 to $1946 \mathrm{bp}$, the major size disparities being due to insertions in the first and second introns. F. valesiaca contained a $235 \mathrm{bp}$ insertion within the first intron, while a $390 \mathrm{bp}$ insertion was present within the second intron for one haplotype derived from $F$. arundinacea subsp. atlantigena. The 8 exons ranged in size from 40 to 188 bp: however there was no size variation between samples within each exon. The 7 introns ranged in size from 73 to $493 \mathrm{bp}$, and each intron displayed more variation between haplotypes than the exons. The total aligned length of the contig was 2254 bp which included 492 variable sites, 199 parsimony informative sites and 112 indels (Table 3). These haplotypes were deposited in GenBank under the accession numbers HM453077 HM453124 and the final sequence alignment is included as Additional File 4.

\section{CEN}

As for Acc1, in the majority of instances the number of haplotypes recovered for a given species was equivalent to the predicted sub-genome number (Table 1). The exceptions were $F$. arundinacea subsp. letourneuxiana and the two Mediterranean morphotype tall fescue varieties Resolute and PG4012, for which haplotype number was one less than the ploidy level, and the octoploid $F$. arundinacea subsp. atlantigena, from which only two haplotypes were recovered. The amplified gene fragment ranged in size from 903 to $958 \mathrm{bp}$ and contained 4 exons, 3 introns and a region of the 3'-untranslated region (UTR). The 4 exons ranged in size from 41 to $218 \mathrm{bp}$, also exhibiting no size variation between species and haplotypes. Greater variation was observed between species with respect to intron length, as well as the size of the 3'-UTR which ranged from 42 to $56 \mathrm{bp}$ in size. The total aligned length of the contig was $972 \mathrm{bp}$, which included 275 variable sites, 122 parsimony informative sites and 44 indels (Table 3 ). The haplotypes were deposited in GenBank under the accession numbers HM453125 - HM453172 and the final sequence alignment is included as Additional File 5.

\section{Phylogenetic inference}

ITS

The parsimony analysis yielded 36 most parsimonious trees $(C I=0.738 ; R I=0.828)$, the strict consensus of which is shown in Figure 1. This tree resolved three major lineages, in which clades A and B represent the Schedonorus/Lolium and Festuca sub-genera respectively, and clade $\mathrm{C}$ contains representatives of the Drymanthele and Scariosae sub-genera. Clade A $(71 \%$ of bootstrap) is further resolved into three well-supported groups (A.1, A.2 and A.3, at 99, 100 and 100\% bootstrap levels) which separate the three tall fescue morphotypes. 


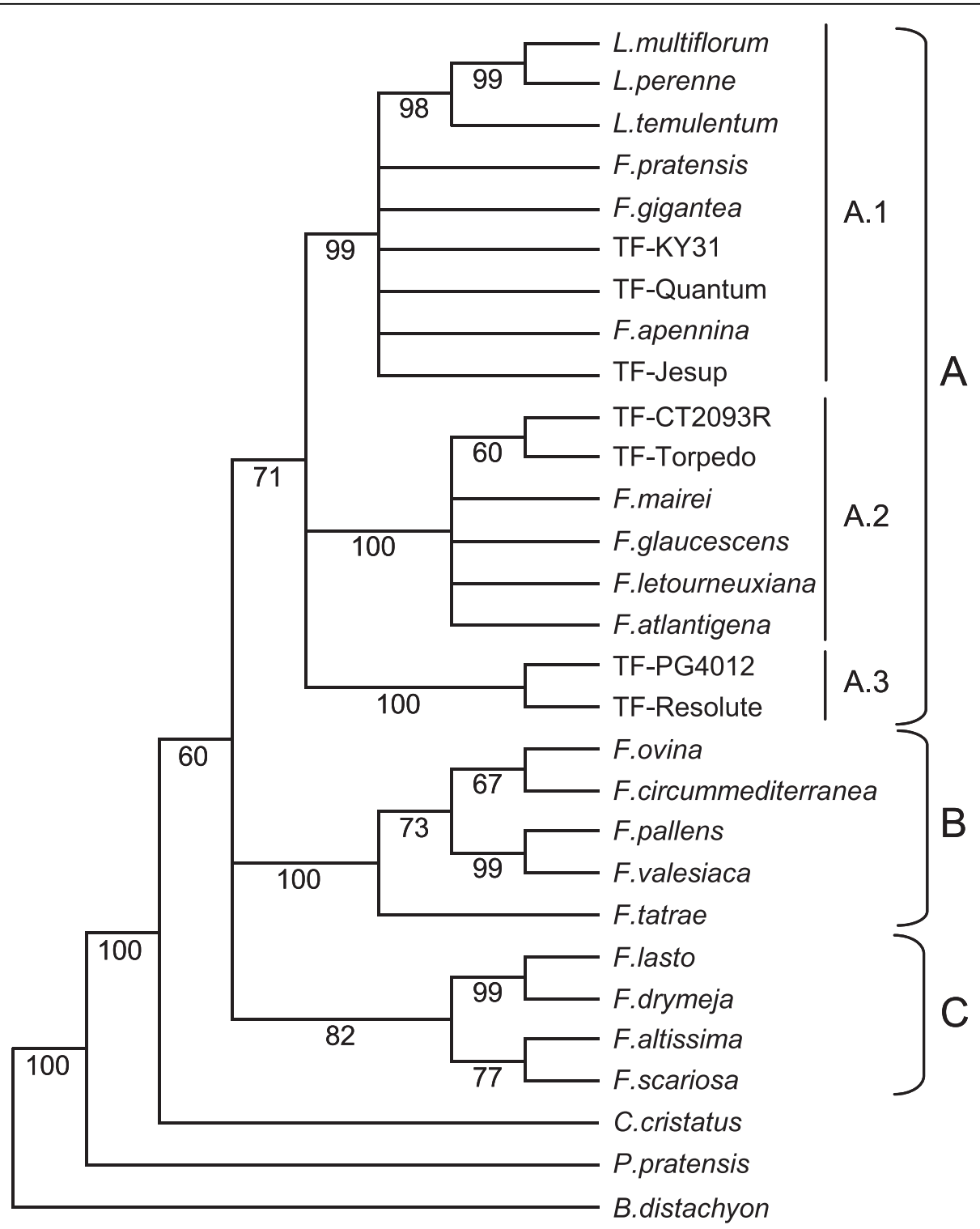

Figure 1 Strict consensus tree obtained from sequence analysis of the nuclear rDNA ITS region. Numbers below branches are bootstrap percentages

A.1 contains the resolved diploid Lolium representatives and six unresolved samples including the three Continental tall fescue varieties, along with one diploid (F. pratensis), one tetraploid (F. pratensis subsp. apennina) and one other hexaploid (F. gigantea). Clade A.2 is composed of the two rhizomatous tall fescue varieties (Torpedo and CT2093R) as well as four unresolved samples (F. mairei, F. arundinacea var. glaucescens, F. arundinacea subsp. letourneuxiana and F. arundinacea subsp. atlantigena), while clade A.3 consists solely of the two Mediterranean tall fescue varieties (Resolute and PG4012). The diploid fine-leaved species of the Festuca sub-genus form group B (100\% of bootstrap), and the third major lineage, $\mathrm{C}$ ( $82 \%$ bootstrap), is composed of three Drymanthele sub-genus representatives, two which share a sister relationship ( $F$. lasto and $F$. dry$m e j a)$, and the third (F. altissima) is related to the one representative of the Scariosae sub-genus (F. scariosa). $C$. cristatus, $P$. pratensis and B. distachyon were outgroups to the entire tree, as anticipated.

matK

A single most parsimonious tree $(\mathrm{CI}=0.943, \mathrm{RI}=$ $0.967)$ resolved into three major clades (A-C) was generated from the heuristic search conducted on the matK data matrix (Figure 2). Clade A was further divided into two well-supported sub-clades (A.1 and A.2: 92\% and 
96\% of bootstrap respectively) and a third less-well supported sub-clade A.3 (64\% of bootstrap). F. arundinacea var. glaucescens and the Continental and rhizomatous tall fescue varieties were unresolved in A.1, while A.2 consists of the three unresolved Lolium species in sister relationships to the unresolved group containing $F$. pratensis, F. pratensis subsp. apennina and F. gigantea. Sub-clade A.3 consists of three unresolved samples $(F$. mairei, $F$. arundinacea subsp. atlantigena and $F$. arundinacea subsp. letourneuxiana) and the two Mediterranean tall fescue varieties. Representatives of the Drymanthele sub-genus comprise clade B (99\% bootstrap), while clade $C$ ( $100 \%$ bootstrap) contains the fineleaved species from the Festuca sub-genus. C. cristatus, $P$. pratensis and $B$. distachyon are out-groups to the entire tree.
Acc1

The heuristic search conducted on the $A c c 1$ data matrix resulted in 504 most parsimonious trees $(\mathrm{CI}=0.830$; $\mathrm{RI}=$ 0.878), the strict consensus of which is shown in Figure 3. This tree can be divided into four major lineages (A-D), in which clades A and B contain representatives of the Schedonorus/Lolium sub-genus, and clades $\mathrm{C}$ and $\mathrm{D}$ are assemblages of the diploids from the Drymanthele and Festuca sub-genera, respectively. Within clade A, haplotypes from $F$. arundinacea subsp. letourneuxiana and $F$. arundinacea subsp. atlantigena, along with an assemblage of $F$. pratensis subsp. apennina and $F$. gigantea, are in sister relationships to the remainder of the clade, which has been further partitioned into sub-clades A.1 and A.2. Sub-clade A.1 (91\% of bootstrap) contains haplotypes from the two Mediterranean tall fescue varieties sister to the rest of A.1,

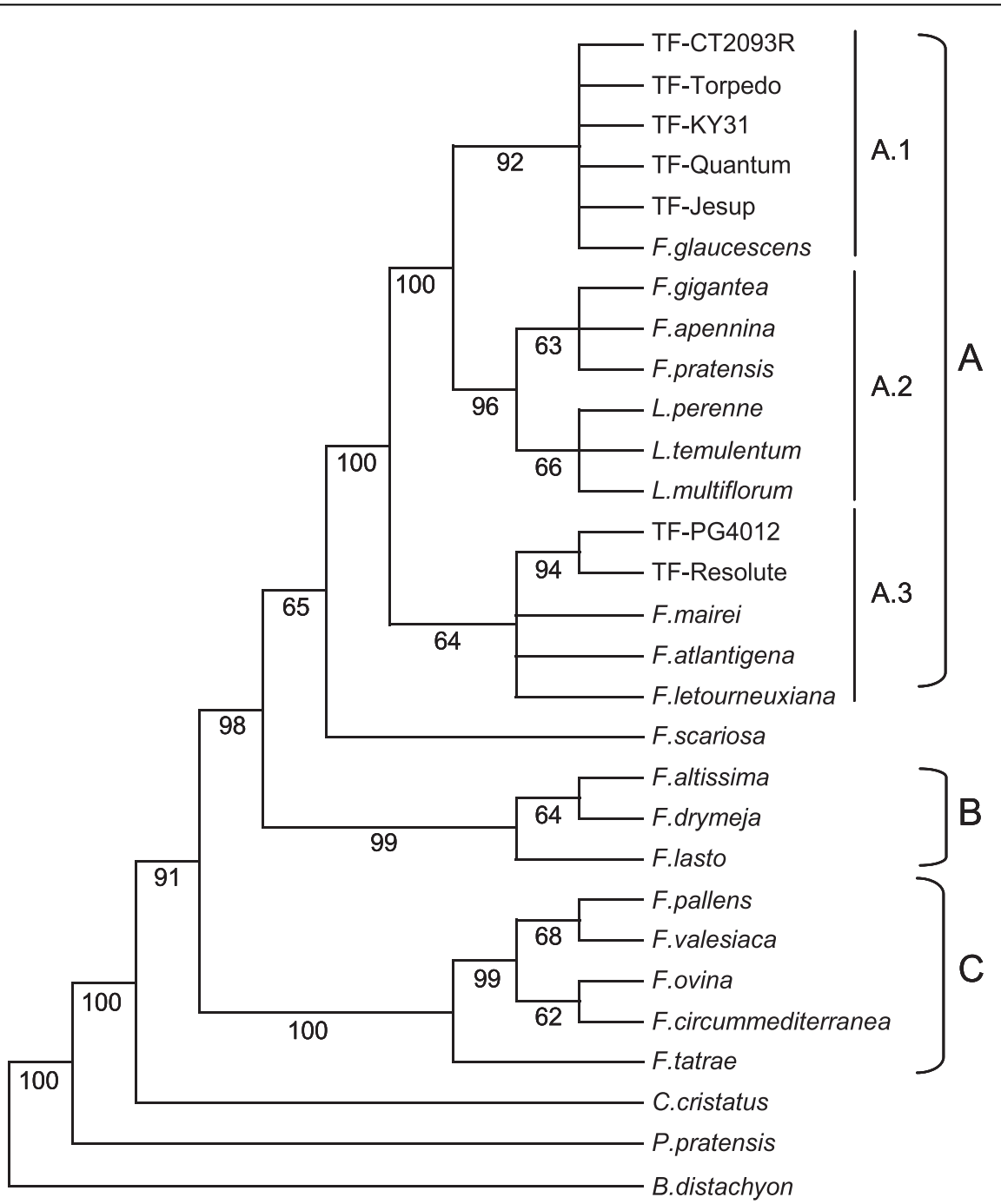

Figure 2 The single most parsimonious tree obtained from sequence analysis of the cpDNA matK gene. Numbers below branches are bootstrap percentages 


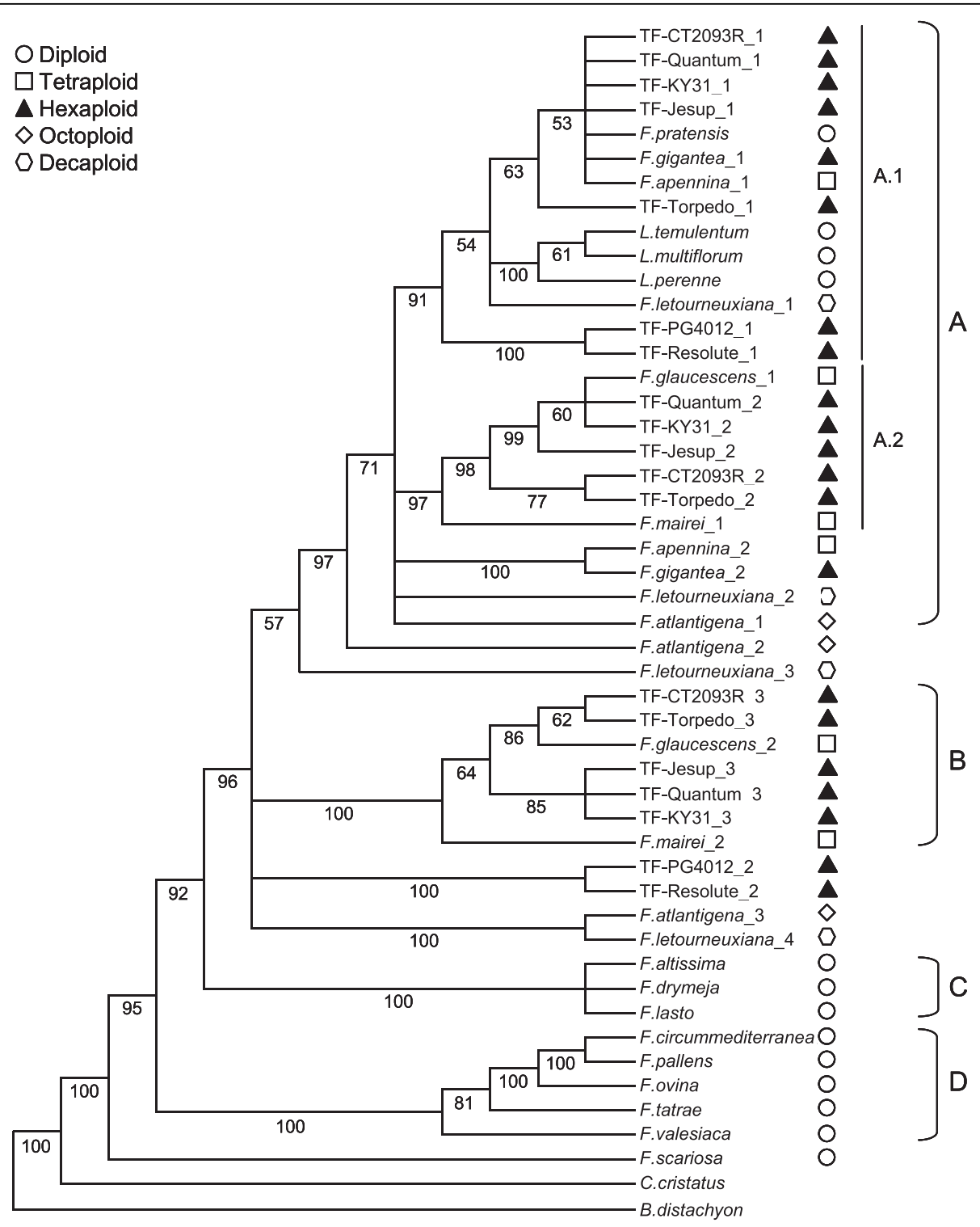

Figure 3 Strict consensus tree obtained from sequence analysis of the nuclear Acc1 gene. Numbers below branches are bootstrap percentages

which includes the monophyletic Lolium species and an unresolved group of one rhizomatous and three Continental tall fescue haplotypes, along with F. pratensis, F. pratensis subsp. apennina and F. gigantea. The second rhizomatous tall fescue variety and a haplotype derived from $F$. arundinacea subsp. letourneuxiana complete subclade A.1. Within sub-clade A.2 (97\% of bootstrap), haplotypes from Continental tall fescue are unresolved from an F. arundinacea var. glaucescens haplotype, while rhizomatous tall fescue haplotypes are sister to this group along with F. mairei. F. arundinacea subsp. letourneuxiana and F. arundinacea subsp. atlantigena haplotypes are basal to the remainder of clade A. Clade B is well supported (100\% of bootstrap) and comprises another group of Continental and rhizomatous tall fescue haplotypes that are related to $F$. arundinacea var. glaucescens and again, this group is sister to F. mairei. Haplotypes of the two Mediterranean tall fescue samples share a sister relationship, as do the higher-order polyploids (F. arundinacea subsp. atlantigena and $F$. arundinacea subsp. letourneuxiana) and these two groups collapse unresolved alongside clade B. Clade C ( $100 \%$ of bootstrap) is an unresolved monophyletic group consisting solely of the three Drymanthele species, while the final clade, D (100\% of bootstrap), contains the fineleaved diploid species of the Festuca sub-genus, in which each species is fully resolved. $F$. scariosa holds the most 
basal position among the Festuca species, with C. cristatus and $B$. distachyon positioned as out-groups.

\section{CEN}

The consensus of 15 most parsimonious trees $(\mathrm{CI}=0.852$, $\mathrm{RI}=0.926)$ derived from the heuristic search of the $C E N$ data matrix is shown in Figure 4. This tree has been divided into five lineages (A-E), in which A, B and C comprise species from the Schedonorus/Lolium sub-genus, D represents the Drymanthele and Scariosae sub-genera and E contains species from the fine-leaved Festuca sub-genus. Within clade A ( $93 \%$ of bootstrap), the sequence of L. multiflorum and haplotypes from F. gigantea, F. arundinacea subsp. letourneuxiana are positioned as sister to two well supported sub-clades (A.1 and A.2). Sub-clade A.1 (100\% of bootstrap) is formed from the Continental and rhizomatous tall fescue varieties and unresolved haplotypes from $F$. pratensis, $F$. pratensis subsp. apennina and F. gigantea. The Mediterranean varieties, along with the L. temulentum-derived sequence, then comprise the remainder of A.1. Sub-clade A.2 (89\% of bootstrap) again demonstrates close relationships between haplotypes from Continental and rhizomatous tall fescue varieties, and also contains unresolved haplotypes from $F$. arundinacea var. glaucescens, F. mairei, F. arundinacea subsp. atlantigena, and $F$. arundinacea subsp. letourneuxiana. This monophyletic group is near identical to clade C (77\% of bootstrap), which contains haplotypes from all of the same species and displays equivalent structure for $F$. arundinacea var. glaucescens, F. mairei, F. arundinacea subsp. atlantigena, and $F$. arundinacea subsp. letourneuxiana which are again, all unresolved. The remainder of the Schedonorus/ Lolium-derived haplotypes are either resolved into the small clade B ( $F$. gigantea, $F$. pratensis subsp. apennina and L. perenne: $97 \%$ of bootstrap) or are positioned as outgroups to both clades A and B (both Mediterranean varieties and $F$. arundinacea subsp. letourneuxiana). The diploids of the Drymanthele sub-genus are unresolved within clade D ( $97 \%$ of bootstrap), which also contains the only representative of the Scariosae sub-genus (F. scar$i o s a$ ), while clade $\mathrm{E}$ is a well supported (100\% of bootstrap) monophyletic group containing species from the diploid fine-leaved Festuca sub-genus. C. cristatus and B. distachyon form out-groups.

\section{Congruence between nuclear gene-derived data sets}

The Acc1 and CEN gene-derived phylogenetic trees share similar structure, particularly with respect to relationships between the three tall fescue morphotypes and the division of other Schedonorus haplotypes. Both trees reveal comparable evolutionary patterns, $A c c 1$ clade A corresponding to $C E N$ sub-clade A, and $A c c 1$ clade B corresponding to most of $C E N$ clade $C$. The remaining $A c c 1$ clades $\mathrm{C}$ and $\mathrm{D}$ correspond to lineages $\mathrm{D}$ and $\mathrm{E}$ in the $C E N$-derived dendrogram. The larger source of discordance between the two data sets arises with respect to the Lolium species and to $F$. scariosa. While the Acc1 gene demonstrates little distinction between the three sampled Lolium species, which form a monophyletic group within the $F$. pratensis-containing subclade A.1, the $C E N$ gene detects a much higher level of variation, such that the three species are distributed throughout the phylogenetic tree in different clades (A.1 - L. temulentum, A - L. multiflorum and B - L. perenne). Similarly, F. scariosa exchanges clade location between the two data sets. Within the Acc1 gene-derived dendrogram, this species is in a basal position to all other Festuca/Lolium species, whereas it is positioned as sister to Drymanthele sub-genus species in the CEN phylogenetic tree. The Incongruence Length Difference test implies significant incongruence between the two nuclear gene data sets $(\mathrm{p}=0.01)$.

\section{Discussion}

\section{Phylogenetic relationships between each tall fescue morphotype}

This phylogenetic study has, for the first time, assessed evolutionary relationships between the three morphotypes of hexaploid tall fescue, which are distinct in geographical and morphophysiological terms. The dendrograms generated from both of the nuclear genederived data sets suggest that representatives of the Mediterranean morphotype are genetically distinct from the Continental and rhizomatous varieties sampled here, supporting the observations of hybrid sterility between tall fescue morphotypes [38,39]. It may be assumed that, for each nuclear gene, the three haplotypes recovered from the Continental tall fescue varieties represent the three sub-genomes, as in each case the relevant haplotypes are closely associated with counterparts from F. pratensis and F. arundinacea var. glaucescens. The Mediterranean morphotype-derived nuclear sequences are, however, more distantly related to these progenitor species, implying that they (or closely related taxa) did not participate as direct ancestors of this morphotype. Both the ITS- and matK gene-derived dendrograms also support an alternative polyploid origin for the Mediterranean morphotype, despite inability to resolve to the level of individual sub-genomes. For each of these data sets, the Mediterranean varieties fail to be closely associated with either $F$. pratensis or F. arundinacea var. glaucescens, in contrast to the Continental and rhizomatous samples.

Full interpretation of taxon origin for the polyploid Mediterranean morphotype is rendered difficult due to the recovery of only two distinct sequence haplotypes for each of the nuclear genes. The two Mediterranean variety-derived genotypes may be confidently predicted to be hexaploid in nature, despite a relatively lower estimated 


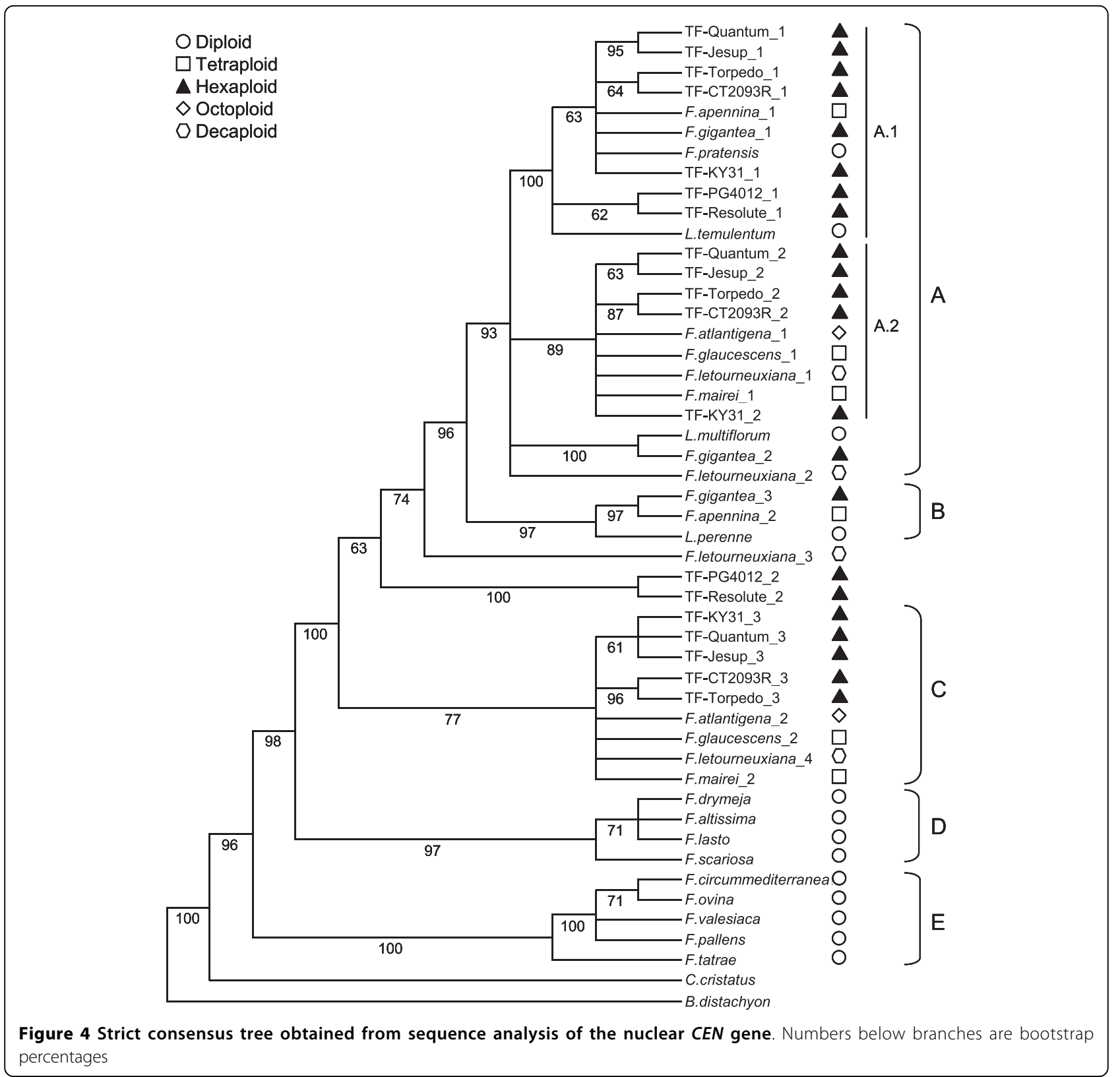

genome size as compared to the Continental varietal individuals. This observed difference in genome size was not unexpected, as previous studies have consistently reported lower flow cytometric measurement values from confirmed hexaploid Mediterranean accessions when compared to the samples from the Continental morphotype [79]. Therefore, a relatively trivial explanation for the observation of only two haplotypes is that three distinct sub-genomes are actually present in the Mediterranean morphotype, but one sub-genome is sufficiently diverged from the template primer sequence to be inefficiently amplified and hence under-represented in, or absent from, the contig assemblies. However, the success observed with the $A c c 1$ and $C E N$-directed primer pairs across a diverse species range, including more distantly related taxa such as $C$. cristatus, suggests that this interpretation is unlikely. In addition, the depth of sequencing employed proved more than sufficient to recover all three haplotypes from the Continental and rhizomatous tall fescue samples. Alternatively, only two sequence variants may be present in the Mediterranean hexaploids, raising the possibility of an autotetraploid progenitor. In order for disomic inheritance to operate in the contemporary hexaploid, preferential pairing must have arisen between chromosomes of the paired sub-genomes, possibly due to genetic divergence [80], later reinforced by 
homoeologous pairing gene control [81]. Confirmation of this model would depend on demonstration of haplotype number deficit across a broader selection of nuclear genes, and, ideally, identification of a contemporary autotetraploid taxon related to the putative ancestor. However, no potential progenitors of the Mediterranean morphotype were identified in this study. Such species may be extinct, or have failed to be sampled in taxonomic studies. If still extant, any such progenitors are likely to be taxonomically classified in the Schedonorus sub-genus and be located in a similar region (Northern Africa/Western Mediterranean) to both Mediterranean tall fescue and the higher polyploids $F$. arundinacea subsp. atlantigena and $F$. arundinacea subsp. letourneuxiana. No diploid ancestors of any of the western Mediterranean species (identified by Figure 1 clade A.2) have yet been identified, and so may have become extinct as a result of climate changes associated with glaciation periods, or, less likely, have evaded discovery [1].

The results of this study indicate a close relationship between the Continental and rhizomatous morphotypes, at least for the varieties sampled here, as they are closely associated in both the nuclear gene dendrograms, while displaying sufficient nucleotide variation to be fully resolved from each other. In each instance, the rhizomatous morphotype putative sub-genomic haplotypes are as equally related to $F$. pratensis and $F$. arundinacea var. glaucescens as those of Continental individuals, suggesting that these two morphotypes share the same progenitors. The ITS-derived data set provides a distinct indication for separation by a large evolutionary distance, as the Continental and rhizomatous samples are positioned in the 'European' (Clade A.1) and 'Maghrebian' (Clade A.2) sub-clades, respectively. These two sub-clades reflect geographical structure and consistently segregate between the Northern European and African/Western Mediterranean Schedonorus species in previous phylogenetic studies performed with ITS sequence $[1,4,5]$. Information on shared diploid ancestry, however, cannot be obtained through comparison of ITS sequence, as the contributions of each parental genome are generally homogenised to one sequence through the action of either gene conversion or non-homologous unequal crossing-over [82-85]. The evidence of the ITSderived dendrogram therefore only indicates that the Continental and rhizomatous morphotypes have evolved independently over a sufficient duration to permit differential ITS homogenisation events.

\section{Phylogenetic inferences from ITS- and matK-derived sequence data}

The overall general structure of the dendrogram generated from the ITS data set is consistent with those previously published [1,3-6]. As in these studies, the results support the taxonomic classification of Clayton and Renvoize [2] and early divergence of the broad- and fineleaved Festuca species. A lower level of basal resolution was achieved here, however, as the Schedonorus, Festuca and Drymanthele sub-genera form three sister clades (Figure 1, Clades A, B, C) rather than the usual two representing the broad-leaved (Schedonorus and Drymanthele subgenera) and fine-leaved (Festuca sub-genus) species. As clades A and C are less strongly supported (71 and $82 \%$ of bootstrap), this disparity is most likely due to minor differences in phylogenetic methodology. In contrast, the matK gene was able to effectively resolve the broad and fine-leaved species, and also provided a higher level of resolution in the Schedonorus sub-genus (Figure 2, Clade A). Previous phylogenetic analysis of the Festuca genus using chloroplast-derived sequence was performed using the trnL-trnF intergenic spacer [5] and achieved similar resolution to that produced here. The main difference between the ITS- and matK-derived dendrograms is the highly supported ( $92 \%$ of bootstrap) formation of sub-clade A.1 (Figure 2) from the matK data set, which segregates $F$. arundinacea var. glaucescens and both the Continental and rhizomatous tall fescue samples from the remaining 'European' Schedonorus/Lolium species. As the chloroplast genome is almost always inherited solely from the female parent, this assemblage probably indicates that a taxon closely related to $F$. arundinacea var. glaucescens has provided the maternal genome for both the Continental and rhizomatous tall fescue morphotypes. The Mediterranean varieties form a close association with $F$. mairei and the higher polyploids $F$. arundinacea subsp. atlantigena and $F$. arundinacea subsp. letourneuxiana in the mat $K$ dendrogram, which raises the possibility of these polyploids sharing a maternal ancestor. While this close relationship with $F$. mairei is not supported by data from the two nuclear genes, it is not feasible to determine whether this is due to the absence of three distinct haplotypes from the Mediterranean varieties or if the association from the chloroplast data is an aberration as a result of low phylogenetic resolution. The matK gene analysis, in summary, predicts $F$. pratensis as the maternal genome donor of $F$. gigantea and $F$. pratensis subsp. apennina, while one of the $\mathrm{G}_{1}$ or $\mathrm{G}_{2}$ progenitor genomes appears to have contributed the maternal genome of $F$. arundinacea var. glaucescens and both the Continental and rhizomatous tall fescue morphotypes. Mediterranean tall fescue shares a maternal origin with $F$. mairei and the higher polyploids $F$. arundinacea subsp. atlantigena and $F$. arundinacea subsp. letourneuxiana.

\section{Possible diploid origins of polyploid Festuca species}

Although the nuclear gene-derived data sets confirm $F$. pratensis and F. arundinacea var. glaucescens as 
probable progenitors of Continental tall fescue, the diploid origins of the $G_{1}$ and $G_{2}$ sub-genomes of F. arundinacea var. glaucescens could not be determined from either dendrogram. The results do, however, permit some previously proposed diploid species to be excluded as candidate sub-genome donors. F. altissima and $F$. scariosa have been previously suggested as diploid progenitors of Continental tall fescue based on morphological comparisons [15] and comparison of chromosome structure [21], but sequences from these two species were never closely associated with any tall fescue haplotype in this phylogenetic analysis. The present results do support cytogenetic studies that indicate an allotetraploid origin for $F$. arundinacea var. glaucescens [13], as two distinct haplotypes are observed, and that $F$. pratensis did not contribute either sub-genomes [19]. It has been further proposed that $F$. arundinacea var. glaucescens and F. mairei may share a diploid subgenome, based on chromosome structure and the formation of bivalents in hybrids $[21,86]$. The nuclear gene analysis here indicate a high degree of similarity between both sub-genomes of these tetraploids, to the extent that they are unresolved in the CEN gene-derived dendrogram. Sequence from the ITS region was also unable to resolve the two species, and only the chloroplast matK gene data set suggests a large evolutionary distance, possibly due to different maternal progenitor taxa.

As the number of recovered nuclear gene haplotypes failed to correspond to the number of expected diploid sub-genomes, resolution of genomic constitutions for the higher polyploids $F$. arundinacea subsp. atlantigena (octoploid) and $F$. arundinacea subsp. letourneuxiana (decaploid) has not been possible. Nonetheless, the two sub-species are minimally differentiated in all the dendrograms, and contain haplotypes that cannot be resolved from those of $F$. arundinacea var. glaucescens and F. mairei in the $C E N$ gene-derived dendrogram. As the $A c c 1$ data set provides higher resolution, the association appears more distant, but it is clear that both $F$. arundinacea var. glaucescens and F. mairei are closely related to the higher polyploids, and either may have contributed to the formation of these species. Crosses of the two tetraploids produce fertile hybrids that resemble $F$. arundinacea subsp. atlantigena, further supporting the speculation that such a hybridisation occurred naturally to produce the octoploid [13]. In this case, the absence of four haplotypes from $F$. arundinacea subsp. atlantigena may be due to the inability to discriminate between the $F$. arundinacea var. glaucescens and $F$. mairei sub-genome components, which are poorly resolved at the species level by nuclear gene analysis.

All of the phylogenetic trees support strong evolutionary relationships between the 'European' fescue species
(F. pratensis, F. pratensis subsp. apennina and F. gigantea). Data from both of the nuclear genes suggest that the hexaploid F. gigantea was formed through the hybridisation of $F$. pratensis subsp. apennina and another diploid species, and that F. pratensis is only one of the diploid progenitors of $F$. pratensis subsp. apennina. This is consistent with previous studies demonstrating the allopolyploid nature of $F$. pratensis subsp. apennina [87] and a common diploid sub-genome (related to $F$. pratensis) between tall fescue and F. gigantea [22].

\section{Phylogenetic utility of Acc1 and CEN genes}

The location of the B. distachyon Acc1 and CEN orthologues on chromosomes 5 and 4 , respectively, is consistent with known macrosynteny between the Triticeae cereals, Poeae grasses and $B$. distachyon $[64,65,65,69]$ and further supports the positioning of these loci on different homoeologous groups within tall fescue. A considerable degree of confidence may therefore be placed in conclusions of hybrid origin, as they are supported by data from two unlinked loci, rather than a single nuclear gene. Both data sets predict very similar relationships between the Festuca species, the higher resolution achieved from $A c c 1$ being probably due to the result of greater sequence length and the presence of 7 introns (in contrast to 3 in $C E N$ ), which provide a greater level of nucleotide variation as compared to exons. While the Acc1 gene has previously been demonstrated to be effective for clarification of the hybrid origin of polyploid species through phylogenetic reconstruction [59-61], this was the first recorded assessment of $C E N$ utility. This gene was originally selected due to verified low copy number in perennial ryegrass [62], along with the presence of introns and ability to be amplified as a single product from the range of species used here. The $C E N$ dendrogram was able to confirm the majority of evolutionary relationships observed from the $A c c 1$ data set, but the observed polyphyly of Lolium species is inconsistent with all other phylogenetic studies, and is possibly an effect of differential selection acting on genes involved in reproductive morphogenesis. Although the multilocus approach used here is crucial for providing independent estimates of evolutionary history, the subsequent independent history of each loci must be considered. Acc1 may be described as a 'housekeeping' gene, as it is involved in fatty acid biosynthesis and is hence likely to be subject to strong but even selective pressure across a large range of species. $C E N$, in contrast, is involved in flowering time control, and represses flowering by maintaining the unfixed identity of the inflorescence meristem [62]. Experiments have shown that this gene, among others, is involved in extending the vegetative state of the plant [88-91]. It is therefore possible that $C E N$ is under different selective pressure in different species, depending on their geographical distribution and habitat, and that the nucleotide variation reflects 
these pressures. It is interesting that such variation is only apparent within the Lolium species, for which variation in annual-perennial growth habit and floral induction requirements has been well documented. The evolutionary lineages described by $C E N$ for the remaining Festuca species are the same as those predicted for Acc1. In general, the $C E N$ gene can be described as useful for phylogenetic reconstruction in the Festuca/Lolium genera, as it confirmed the majority of relationships produced by $A c c 1$ and the ITS data sets. The unexpected placement of Lolium species reinforces the importance of comparison between data from multiple unlinked loci when assessing evolutionary relationships.

\section{Future implications}

The results of this study have contributed to the understanding of evolutionary relationships within a group of grass species for which previous taxonomic classifications have been contentious. In particular, a further revision of systematics to recognise the Mediterranean and Continental morphotypes of tall fescue as separate taxa appears to be warranted. The implications of these results, however, reach beyond taxonomy and have the potential to impact on molecular breeding strategies. For example, the demonstration of independent evolution between the Mediterranean and Continental morphotypes suggests sufficient nucleotide variation to allow development of molecular genetic markers capable of discrimination, to enable an uncomplicated germplasm screening method which is simpler and cheaper than sequencing. The ability to distinguish sequences from all three sub-genomes of Continental and rhizomatous tall fescue in this study also has implications for the generation of sub-genome-specific genetic markers, such as single nucleotide polymorphism assays, as has been demonstrated for the outbreeding allotetraploid forage species white clover (Trifolium repens L.) [92]. This result implies that the diversity between each sub-genome is sufficient to design sub-genome specific primers, and ultimately detect DNA sequence polymorphisms that are able to attribute homoeologous linkage groups to specific sub-genomes and putative progenitor origins $[92,93]$.

\section{Conclusions}

This study describes the first phylogenetic analysis of the Festuca genus to include each of the three tall fescue morphotypes (Continental, Mediterranean and rhizomatous) and has used low copy nuclear gene sequences to identify progenitors of the polyploid species. F. pratensis and $F$. arundinacea var. glaucescens were confirmed as the probable progenitors of Continental tall fescue, and also as likely ancestors of the rhizomatous morphotype, although these two morphotypes are sufficiently diverse to be positioned in separate clades based on ITS analysis.
Phylogenetic reconstruction of all four data sets suggests that Mediterranean tall fescue has evolved independently from both other morphotypes, as a result from hybridisation of different diploid progenitors. These results have implications for taxonomic revision, as well as molecular breeding strategies, and will facilitate the generation of both morphotype and sub-genome-specific molecular genetic markers.

\section{Additional material}

\begin{abstract}
Additional file 1: Relative genome size of each sample. Genome size was calculated relative to $F$. pratensis, using measurements from both the Ploidy Analyser and previously published estimates. For each sample, Ploidy Analyser measurements represent the average of two readings, with the exception of tall fescue varieties, for which four measurements were made. The previously published estimates represent an average of the respective genome sizes, as reported in multiple prior publications. The extent of error bars represent the standard error of the mean.

Additional file 2: Sequence alignment of the ITS region. Sequence alignment, in NEXUS format, used to generate the ITS phylogenetic tree Additional file 3: Sequence alignment of matK. Sequence alignment, in NEXUS format, used to generate the matK phylogenetic tree

Additional file 4: Sequence alignment of Acc1. Sequence alignment, in NEXUS format, used to generate the Acc1 phylogenetic tree

Additional file 5: Sequence alignment of CEN. Sequence alignment, in NEXUS format, used to generate the CEN phylogenetic tree
\end{abstract}

\section{Acknowledgements}

The authors acknowledge the contribution of plant material from the Genetic Resources Unit of IBERS, Aberystwyth, Wales and particularly the efforts of lanto Thomas. This work represents part of a PhD degree for $\mathrm{MH}$ who is supported by an Australian Postgraduate Award. The work was also supported by funding from the Victorian Department of Primary Industries, Dairy Australia Ltd., the Geoffrey Gardiner Dairy Foundation, Meat and Livestock Australia Ltd. and the Molecular Plant Breeding Cooperative Research Centre (MPB CRC). The authors thank Prof. German Spangenberg for careful critical reading of the manuscript.

\section{Author details}

${ }^{1}$ Department of Primary Industries, Biosciences Research Division, Victorian AgriBiosciences Centre, 1 Park Drive, La Trobe University Research and Development Park, Bundoora, Victoria 3083, Australia. ${ }^{2}$ Molecular Plant Breeding and Dairy Futures Cooperative Research Centres, Australia. ${ }^{3}$ La Trobe University, Bundoora, Victoria 3086, Australia. ${ }^{4}$ PGG Wrightson Seeds, P. O. Box 175, Lincoln 7640, Canterbury, New Zealand.

\section{Authors' contributions}

$\mathrm{MH}$ carried out the ploidy analysis, extracted the DNA, generated the DNA sequences, performed the phylogenetic analysis and drafted the manuscript. $\mathrm{NC}$ and JF co-conceptualised and coordinated the project, contributed to data interpretation and assisted in drafting the manuscript. AS provided plant material, contributed to data interpretation and assisted in drafting the manuscript. All authors read and approved the final manuscript.

Received: 2 June 2010 Accepted: 12 October 2010

Published: 12 October 2010

\section{References}

1. Inda LA, Segarra-Moragues JG, Müller J, Peterson PM, Catalán P: Dated historical biogeography of the temperate Loliinae (Poaceae, Pooideae) grasses in the northern and southern hemispheres. Molecular Phylogenetics and Evolution 2008, 46(3):932-957. 
2. Clayton W, Renvoize S: Genera graminum. London, UK: Kew Publishing 1986.

3. Charmet G, Ravel C, Balfourier F: Phylogenetic analysis in the FestucaLolium complex using molecular markers and ITS rDNA. TAG Theoretical and Applied Genetics 1997, 94(8):1038.

4. Torrecilla P, Catalán P: Phylogeny of broad-leaved and fine-leaved Festuca lineages (Poaceae) based on nuclear ITS sequences. Systematic Botany 2002, 27(2):241-251.

5. Catalán P, Torrecilla P, Rodríguez JÁL, Olmstead RG: Phylogeny of the festucoid grasses of subtribe Loliinae and allies (Poeae, Pooideae) inferred from ITS and trnL-F sequences. Molecular Phylogenetics and Evolution 2004, 31(2):517-541.

6. Gaut BS, Tredway LP, Kubik C, Gaut RL, Meyer W: Phylogenetic relationships and genetic diversity among members of the FestucaLolium complex (Poaceae) based on ITS sequence data. Plant Systematics and Evolution 2000, 224(1):33-53.

7. Loureiro J, Kopecký D, Castro S, Santos C, Silveira P: Flow cytometric and cytogenetic analyses of Iberian Peninsula Festuca spp. Plant Systematics and Evolution 2007, 269(1):89-105.

8. Smarda P, Bures P, Horova L, Foggi B, Rossi G: Genome size and GC content evolution of Festuca: ancestral expansion and subsequent reduction. Annals of Botany 2008, 101(3):421-433.

9. Terrell EE: A taxonomic revision of the genus Lolium. Technical Bulletin of the United States Department of Agriculture 1968, 1392.

10. Scholz H, Ch S, Gaisberg MV: Lolium edwardii sp. nova (Gramineae) and its relationship with Schedonorus sect. Plantynia Dumort. Feddes Repertorium 2000, $111(7-8): 561-565$.

11. Scholz S, Scholz H: A new species of Lolium (Gramineae) from Fuerteventura and Lanzarote (Canary Islands, Spain). Willendowia 2005, 35:281-286

12. Darbyshire S: Realignment of Festuca subgenus Schedonorus with the genus Lolium (Poaceae). Novon 1993, 3:239-243.

13. Chandrasekharan P, Thomas H: Studies in Festuca. V. Cytogenetic relationships between species of Bovinae and Scariosae. Zeitschrift fur Pflanzenzuchtung 1971, 65:353-354.

14. Borrill M, Kirby MW, Morgan G: Studies in Festuca 11. Interrelationships of some putative diploid ancestor of the polyploid broad-leaved fescues. New Phytologist 1977, 78(3):661-674.

15. Borrill M, Kirby M, Morgan G: Studies in Festuca 12. Morphology, distribution and cytogenetics of $F$. donax, F. scariosa and their hybrids, and the evolutionary significance of their fertile amphiploid derivative. New Phytologist 1980, 86(4):423-439.

16. Malik CP, Thomas PT: Karyotypic studies in some Lolium and Festuca species. Caryologia 1966, 19:167-196.

17. Malik CP, Thomas PT: Cytological relationship and genome structure of some Festuca species. Caryologia 1967, 20:1-39.

18. Seal AG: DNA variation in Festuca. Heredity 1983, 50(3):225-236.

19. Humphreys MW, Thomas HM, Morgan WG, Meredith MR, Harper JA, Thomas H, Zwierzykowski Z, Ghesquiere M: Discriminating the ancestral progenitors of hexaploid Festuca arundinacea using genomic in situ hybridization. Heredity 1995, 75(2):171-174.

20. Pasakinskiene I, Anamthawat-Jonsson K, Humphreys MW, Paplauskiene V, Jones RN: New molecular evidence on genome relationships and chromosome identification in fescue (Festuca) and ryegrass (Lolium). Heredity 1998, 81(6):659-665.

21. Harper JA, Thomas ID, Lovatt JA, Thomas HM: Physical mapping of rDNA sites in possible diploid progenitors of polyploid Festuca species. Plant Systematics and Evolution 2004, 245(3):163-168.

22. Thomas HM, Harper JA, Meredith MR, Morgan WG, King IP: Physical mapping of ribosomal DNA sites in Festuca arundinacea and related species by in situ hybridization. Genome 1997, 40:406-410.

23. Xu WW, Sleper DA: Phylogeny of tall fescue and related species using RFLPs TAG. Theoretical and Applied Genetics 1994, 88(6):685-690.

24. Stammers M, Harris J, Evans GM, Hayward MD, Forster JW: Use of random PCR (RAPD) technology to analyse phylogenetic relationships in the Lolium/Festuca complex. Heredity 1995, 74(1):19-27.

25. Reed KFM, Clement SL, Feely WF, Clark B: Improving tall fescue (Festuca arundinacea) for cool-season vigour. Australian Journal of Experimental Agriculture 2004, 44(9):873-881.

26. Robson M: A comparison of British and North African varieties of tall fescue 1. Leaf growth during winter; effects of temperature and day length. Journal of Applied Ecology 1967, 4:475-484.
27. Clement SL, Elberson LR, Youssef NN, Davitt CM, Doss RP: Incidence and diversity of Neotyphodium fungal endophytes in tall fescue from Morocco, Tunisia, and Sardinia. Crop Science 2001, 41(2):570-576.

28. Tsai HF, Liu JS, Staben C, Christensen MJ, Latch GC, Siegel MR, Schardl CL: Evolutionary diversification of fungal endophytes of tall fescue grass by hybridization with Epichloe species. Proceedings of the National Academy of Sciences of the United States of America 1994, 91(7):2542-2546.

29. Gonzalez-Bernaldez F, Borrill M, Lindner R: Variability of hexaploid Festuca arundinacea 1. Principal components analysis of correlation matrix. Boletin de la Real Sociedad Espanola de Historia Natural Seccion Biologica 1969, 67:257-263.

30. Borrill M, Tyler BF, Lloyd-Jones M: Studies in Festuca 1. A chromosome atlas of Bovinae and Scariosae. Cytologia 1971, 36:1-14.

31. Jernstedt JA, Bouton JH: Anatomy, morphology, and growth of tall fescue rhizomes. Crop Science 1985, 25(3):539-542.

32. Anonymous Torpedo Tall Fescue. New Zealand Plant Variety Rights 1994, Grant number FESO07.

33. Stewart AV: World First - Tall fescue with rhizomes. New Zealand Turf Management Journal 1995, 9:32.

34. Stewart AV: The development of a rhizomatous tall fescue (Festuca arundinacea) cultivar. 8th International Turfgrass Research Conference: 1997 Sydney, Australia 1997, 136-138.

35. Charrier S, Stewart AV: Breeding of rhizomatous turf tall fescue. 13th Australasian Plant Breeding Conference: 2006 Christchurch, New Zealand 2006, 383-1387.

36. de Bruijin J: Tall fescue variety having rhizomes. Barenbrug USA, InC (Tanget, OR) United States 2004, Patent number 6677507.

37. Ghesquiere M, Jadas-Hecart J: Les fe'tuques ou le genre Festuca. In Ressources ge'ne'tiques des plantes fourrage' res et a' gazon. Edited by: Prosperi J-Mea. St-Just-La-Pendue, France: BRG; 1995:

38. Hunt KL, Sleper DA: Fertility of hybrids between two geographic races of tall fescue. Crop Science 1981, 21(3):400-404.

39. Malik CP, Thomas PT: Chromosomal polymorphism in Festuca arundinacea. Chromosoma 1966, 18(1):1-18.

40. Lewis EJ: Hybrids between geographical races of Festuca arundinacea Schreb. Reports of the Welsh Plant Breeding Station 1963, 26-27.

41. Jadas-Hecart J, Gillet M: Problems posed by sterile hybrids between two types of tall fescues European and Mediterranean. Meeting of the Fodder Crops Section of Eucarpia 1973 Wageningen, the Netherlands 1973.

42. Drummond JD: The effect of hybridisation on seed vigour of Continental and Mediterranean tall fescue (Festuca arundinacea Schreb.) crosses. Dissertation Thesis Lincoln University, New Zealand 2006.

43. Jauhar PP: Recent cytogenetics of the Festuca-Lolium complex. In Chromosome Engineering in Plants: Genetics, Breeding, Evolution. Edited by: Tsuchiya T, Gupta PK. Amsterdam, Netherlands: Elsevier Science Publishers; 1991:2B:325-362.

44. Jauhar PP: Genetic regulation of diploid-like chromosome pairing in the hexaploid species, Festuca arundinacea Schreb. and F. rubra L (Gramineae). Chromosoma 1975, 52(4):363-382.

45. Jauhar PP: Genetic control of diploid-like meiosis in hexaploid tall fescue. Nature 1975, 254(5501):595-597.

46. Berg CC, Webster GT, Jauhar PP: Cytogenetics and genetics. In Tall Fescue. Edited by: Buckner RC, Bush LP. Madison, Wisconsin: American Society of Agronomy; 1979:93-109.

47. Eizenga GC, Kasperbauer MJ: Chromosome pairing in tall fescue haploids derived by anther-panicle culture. Journal of Heredity 1985, 76(2):99-102.

48. Soltis PS, Soltis DE: The role of genetic and genomic attributes in the success of polyploids. Proceedings of the National Academy of Sciences of the United States of America 2000, 97(13):7051-7057.

49. Sleper DA: Breeding Tall Fescue. In Plant Breeding Reviews. Edited by: Janick J. Westport: AVI Publishing Co; 1985:3:313-342.

50. Sang T: Utility of low-copy nuclear gene sequences in plant phylogenetics. Critical Reviews in Biochemistry and Molecular Biology 2002, 37(3):121-147.

51. Fortune PM, Schierenbeck KA, Ainouche AK, Jacquemin J, Wendel JF, Ainouche ML: Evolutionary dynamics of Waxy and the origin of hexaploid Spartina species (Poaceae). Molecular Phylogenetics and Evolution 2007, 43(3):1040-1055.

52. Huang S, Sirikhachornkit A, Su X, Faris J, Gill B, Haselkorn R, Gornicki P: Genes encoding plastid acetyl-CoA carboxylase and 3-phosphoglycerate kinase of the Triticum/Aegilops complex and the evolutionary history of 
polyploid wheat. Proceedings of the National Academy of Sciences of the United States of America 2002, 99(12):8133-8138.

53. Vilatersana R, Brysting AK, Brochmann C: Molecular evidence for hybrid origins of the invasive polyploids Carthamus creticus and C. turkestanicus (Cardueae, Asteraceae). Molecular Phylogenetics and Evolution 2007. 44(2):610-621.

54. Rousseau-Gueutin M, Gaston A, Aïnouche A, Ainouche ML, Olbricht K, Staudt G, Richard L, Denoyes-Rothan B: Tracking the evolutionary history of polyploidy in Fragaria L. (strawberry): New insights from phylogenetic analyses of low-copy nuclear genes. Molecular Phylogenetics and Evolution 2009, 51(3):515-530.

55. Small RL, Ryburn JA, Cronn RC, Seelanan T, Wendel JF: The tortoise and the hare: choosing between noncoding plastome and nuclear Adh sequences for phylogeny reconstruction in a recently diverged plant group. American Journal of Botany 1998, 85(9):1301-1315

56. Gaut BS, Morton BR, McCaig BC, Clegg MT: Substitution rate comparisons between grasses and palms: synonymous rate differences at the nuclear gene Adh parallel rate differences at the plastid gene rbcL. Proceedings of the National Academy of Sciences of the United States of America 1996, 93(19):10274-10279.

57. Small RL, Cronn RC, Wendel JF: Use of nuclear genes for phylogeny reconstruction in plants. Australian Systematic Botany 2004, 17(2):145-170.

58. Gornicki P, Faris J, King I, Podkowinski J, Gill B, Haselkorn R: Plastidlocalized acetyl-CoA carboxylase of bread wheat is encoded by a single gene on each of the three ancestral chromosome sets. Proceedings of the National Academy of Sciences of the United States of America 1997, 94(25):14179-14184

59. Huang S, Sirikhachornkit A, Faris JD, Su X, Gill BS, Haselkorn R, Gornicki P: Phylogenetic analysis of the acetyl-CoA carboxylase and 3phosphoglycerate kinase loci in wheat and other grasses. Plant Molecular Biology 2002, 48(5):805-820.

60. Zhang C, Fan X, Yu H-Q, Zhang H-Q, Wang X-L, Zhou Y-H: Phylogenetic analysis of questionable tetraploid species in Roegneria and Pseudoroegneria (Poaceae: Triticeae) inferred from a gene encoding plastid acety1-CoA carboxylase. Biochemical Systematics and Ecology 2009, 37(4):412-420.

61. Fan $X$, Sha $L-N$, Yang R-W, Zhang $H-Q$, Kang H-Y, Ding C-B, Zhang L, Zheng Y-L, Zhou Y-H: Phylogeny and evolutionary history of Leymus (Triticeae; Poaceae) based on a single-copy nuclear gene encoding plastid acetyl-CoA carboxylase. BMC Evolutionary Biology 2009, 9(1):247.

62. Jensen CS, Salchert K, Nielsen KK: A Terminal Flower1-Like Gene from Perennial Ryegrass Involved in Floral Transition and Axillary Meristem Identity. Plant Physiol 2001, 125(3):1517-1528.

63. Cogan N, Ponting R, Vecchies A, Drayton M, George J, Dracatos P, Dobrowolski M, Sawbridge T, Smith K, Spangenberg G, et al: Geneassociated single nucleotide polymorphism discovery in perennial ryegrass (Lolium perenne L.). Molecular Genetics and Genomics 2006, 276(2):101-112.

64. Jones ES, Mahoney NL, Hayward MD, Armstead AP, Jones JG, Humphreys MO, King IP, Kishida T, Yamada T, Balfourier F, et al: An enhanced molecular marker based genetic map of perennial ryegrass (Lolium perenne) reveals comparative relationships with other Poaceae genomes. Genome 2002, 45(2):282-295.

65. Sim S, Chang T, Curley J, Warnke SE, Barker RE, Jung G: Chromosomal rearrangements differentiating the ryegrass genome from the Triticeae, oat, and rice genomes using common heterologous RFLP probes. TAG Theoretical and Applied Genetics 2005, 110(6):1011-1019.

66. Alm V, Fang C, Busso CS, Devos KM, Vollan K, Grieg Z, Rognli OA: A linkage map of meadow fescue ( Festuca pratensis Huds.) and comparative mapping with other Poaceae species. TAG Theoretical and Applied Genetics 2003, 108(1):25-40.

67. Hollingsworth PM, Forrest LL, Spouge JL, Hajibabaei M, Ratnasingham S, van der Bank M, Chase MW, Cowan RS, Erickson DL, Fazekas AJ, et al: A DNA barcode for land plants. Proceedings of the National Academy of Sciences 2009, 106(31):12794-12797.

68. Altschul SF, Gish W, Miller W, Myers EW, Lipman DJ: Basic local alignment search tool. Journal of Molecular Biology 1990, 215(3):403-410.

69. Initiative TIB: Genome sequencing and analysis of the model grass Brachypodium distachyon. Nature 2010, 463(7282):763-768.

70. Bennett MD, Leitch IJ: Plant DNA C-values database (release 4.0, Oct. 2005). 2005 [http://www.kew.org/cvalues/].
71. Ceccarelli M, Falistocco E, Cionini PG: Variation of genome size and organization within hexaploid Festuca arundinacea. TAG Theoretical and Applied Genetics 1992, 83(3):273-278.

72. Hsiao C, Jacobs SWL, Chatterton NJ, Asay KH: A molecular phylogeny of the grass family (Poaceae) based on the sequences of nuclear ribosomal DNA (ITS). Australian Systematic Botany 1998, 11(6):667-688.

73. Tamura K, Dudley J, Nei M, Kumar S: MEGA4: Molecular Evolutionary Genetics Analysis (MEGA) Software Version 4.0. Mol Biol Evol 2007, 24(8):1596-1599.

74. Rozas J, Sanchez-DelBarrio JC, Messeguer X, Rozas R: DnaSP, DNA polymorphism analyses by the coalescent and other methods. Bioinformatics 2003, 19(18):2496-2497.

75. Young N, Healy J: GapCoder automates the use of indel characters in phylogenetic analysis. BMC Bioinformatics 2003, 4(1):6.

76. Swofford DL: PAUP*. Phylogenetic Analysis Using Parsimony (*and Other Methods). Version 4.: Sinauer Associates, Sunderland, Massachusetts 2003.

77. Felenstein J: Confidence limits on phylogenies: an approach using the bootstrap. Evolution 1985, 39:783-791.

78. Farris JS, Källersjö M, Kluge AG, Bult C: Testing Significance Of Incongruence. Cladistics 1994, 10(3):315-319.

79. Schardl CL, Craven KD, Schweri KK, Hollin W, Clement SL, Schmid J, West CP, Phillips TD: Endophytes of the tall fescue ploidy series in Europe, North Africa and the Mediterranean. 6th International Symposium on Fungal Endophytes of Grasses: 2007 Dunedin, New Zealand 2007, 456.

80. Jenkins G, Chatterjee BN: Chromosome structure and pairing preferences in autotetraploid rye (Secale cereale). Genome 1994, 37(5):784-793.

81. Le Comber SC, Ainouche ML, Kovarik A, Leitch AR: Making a functional diploid: from polysomic to disomic inheritance. New Phytologist 2010, 186(1):113-122.

82. Kovarik A, Matyasek R, Lim KY, Skalicka K, Koukalova B, Knapp S, Chase M, Leitch AR: Concerted evolution of 18-5.8-26S rDNA repeats in Nicotiana allotetraploids. Biological Journal of the Linnean Society 2004, 82(4):615-625.

83. Franzke A, Mummenhoff K: Recent hybrid speciation in Cardamine (Brassicaceae) - conversion of nuclear ribosomal ITS sequences in statu nascendi. TAG Theoretical and Applied Genetics 1999, 98(5):831-834.

84. Rauscher JT, Doyle JJ, Brown AHD: Internal transcribed spacer repeatspecific primers and the analysis of hybridization in the Glycine tomentella (Leguminosae) polyploid complex. Molecular Ecology 2002, 11(12):2691-2702.

85. Wendel JF, Schnabel A, Seelanan T: Bidirectional interlocus concerted evolution following allopolyploid speciation in cotton (Gossypium). Proceedings of the National Academy of Sciences of the United States of America 1995, 92(1):280-284.

86. Bowman JG, Thomas H: Studies in Festuca. 8. Cytological relationships between $F$. glaucescens $(2 n=28), F$. mairei $(2 n=28)$ and F. scariosa $(2 n$ = 14). Zeitschrift fur Pflanzenzuchtung 1976, 76(3):250-257.

87. Clarke J, Chandrasekharan P, Thomas H: Studies in festuca. 9. Cytological studies of Festuca pratensis var. apennina (De Not) Hack. $(2 n=28)$. Zeitschrift fur Pflanzenzuchtung 1976, 77(3):205-214.

88. Fujiwara S, Nakagawa M, Kamada H, Coupland G, Mizoguchi T: Circadian clock components in Arabidopsis I. The terminal flower 1 enhances the early flowering phenotype of a mutant, Ihy cca1. Plant Biotechnology 2005, 22(4):311-317.

89. Szankowski I, Waidmann S, Omar A, Flachowsky H, Hattasch C, Hanke M: RNAi-silencing of MdTFL1 induces early flowering in apple. Acta Horticulturae 2009, 839:633-636.

90. Hou C-J, Yang C-H: Functional Analysis of FT and TFL1 Orthologs from Orchid (Oncidium Gower Ramsey) that Regulate the Vegetative to Reproductive Transition. Plant Cell Physiol 2009, 50(8):1544-1557.

91. Foucher F, Morin J, Courtiade J, Cadioux S, Ellis N, Banfield MJ, Rameau C: DETERMINATE and LATE FLOWERING Are Two TERMINAL FLOWER1/ CENTRORADIALIS Homologs That Control Two Distinct Phases of Flowering Initiation and Development in Pea. Plant Cell 2003, 15(11):2742-2754.

92. Hand M, Ponting R, Drayton M, Lawless K, Cogan N, Charles Brummer E, Sawbridge T, Spangenberg G, Smith K, Forster J: Identification of homologous, homoeologous and paralogous sequence variants in an outbreeding allopolyploid species based on comparison with progenitor taxa. Molecular Genetics and Genomics 2008, 280(4):293-304. 
93. Blake NK, Sherman JD, Dvořák J, Talbert LE: Genome-specific primer sets for starch biosynthesis genes in wheat. TAG Theoretical and Applied Genetics 2004, 109(6):1295-1302

94. Hilu KW, Alice LA, Liang H: Phylogeny of Poaceae inferred from matK sequence. Annals of the Missouri Botanical Garden 1999, 86(4):835-851.

95. Johnson L, Soltis D: Phylogenetic inference in Saxifragaceae sensu stricto and Gilia (Polemoniaceae) using matK sequences. Annals of the Missouri Botanical Garden 1995, 82:149-175.

doi:10.1186/1471-2148-10-303

Cite this article as: Hand et al:: Evolutionary history of tall fescue morphotypes inferred from molecular phylogenetics of the Lolium-

Festuca species complex. BMC Evolutionary Biology 2010 10:303.

Submit your next manuscript to BioMed Central and take full advantage of:

- Convenient online submission

- Thorough peer review

- No space constraints or color figure charges

- Immediate publication on acceptance

- Inclusion in PubMed, CAS, Scopus and Google Scholar

- Research which is freely available for redistribution

Submit your manuscript at www.biomedcentral.com/submit
Ciomed Central 